\title{
Factors influencing restaurateurs' choice of wines and wine lists: A replication study in a South African context

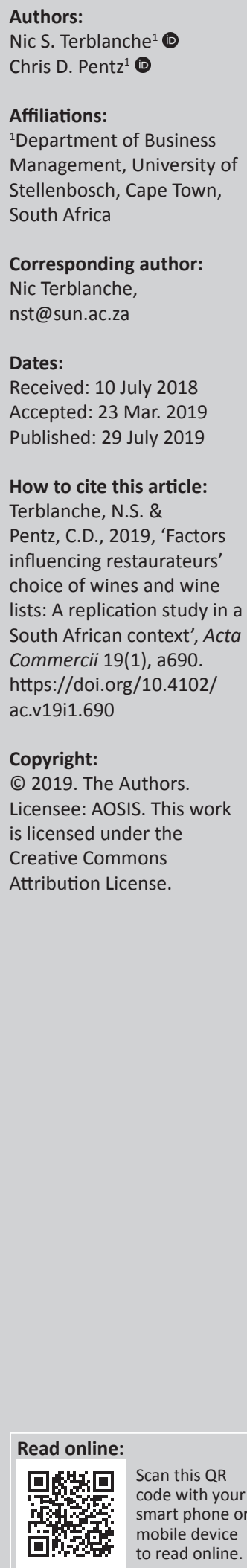

Orientation: The restaurant environment is highly competitive. Restaurants' wine lists offer value, prestige and positive emotional experiences to customers.

Research purpose: The research problem studied here focuses on the factors that restaurateurs consider when they design a wine list for a fine dining restaurant. The objective is to replicate the work of Sirieix et al. (2011) in a South African context.

Motivation for the study: The primary motivation for this study is the absence in academic publications about why and how South African restaurateurs select wines for their wine lists.

Research design, approach and method: Sixty one restaurants offering fine dining, are not part of a franchise and offered wines from other estates and producers were approached and agreed to participate in the study. Personal interviews were conducted with owners, managers or sommeliers. Restaurateurs' strategy preferences were analysed with Finn and Louviere's (1992) Best-Worst methodology.

Main findings: The two individual factors selected the most by South African restaurateurs for inclusion on a wine list, that a wine should match well with the food offered and that it must taste good, are similar to those of the Sirieix et al. (2011) study.

Practical/managerial implications: The findings may enable wine producers and wine marketers to refine their marketing strategies and tactics to restaurants that offer fine dining.

Contribution/value-add: Wine contributes on average $29 \%$ to the turnover of restaurants and is therefore by implication of great importance to customer satisfaction and restaurateurs.

Keywords: wine lists; choice factors; fine dining restaurants; Best-Worst methodology; restaurateurs.

\section{Introduction}

In his book, Death in the Afternoon (1932), Ernest Hemingway describes wine as:

$\ldots$ one of the most civilized things in the world and one of the most natural things of the world that has been brought to the greatest perfection, and it offers a greater range for enjoyment and appreciation than, possibly, any other purely sensory thing which may be purchased. (p. 14)

Originally a natural and simple product, wine has developed into a diverse and complex commodity. Once this unique liquid is bottled and labelled, it transforms and develops a new character and complexity: it can be used as a thirst quencher, a deal clincher, an aphrodisiac or an anaesthetic, to mention only a few of the diverse uses of wine (Keown \& Casey 1995).

Wine can also be purchased in different settings, that is, in an 'off-trade' setting (e.g. at a liquor store) or in an 'on-trade' setting (e.g. at a restaurant). A customer's selection of a bottle of wine in a restaurant refers to a specific consumption event that combines the situation (the place where the wine will be consumed) and the object (the specific wine product that will be consumed) (Davis \& Charters 2006). The food and beverage industry is an important sector of the South African economy. It generated a total nominal income in excess of R42 billion in 2017 (The Department of Agriculture, Forestry and Fisheries [RSA] 2017). It is common knowledge that the restaurant industry is highly competitive and therefore restaurateurs have to create unique dining experiences for increasingly demanding patrons (Saura, Molina \& Contrí 2008). The means available to restaurateurs to differentiate their establishments from competitors include the type and quality of food they offer, the speed of service, convenience, entertainment offered, price, atmosphere and the reputation of the establishment (Peng, Bilgihan \& Kandampully 2015). Another factor at the disposal of restaurateurs to differentiate their establishments from others is the offering of wine, as the combination of fine wine and good food may further enhance the 
dining experience (Aune 2002). Many study disciplines, such as psychology, sociology and anthropology, acknowledge the symbolic connection between food and alcohol (Pettigrew \& Charters 2006). Even the French gastronome, Anthelme Brillat-Savarin (1755-1826), once proclaimed that 'a meal without wine is like a day without sunshine' (Top Wine SA n.d.).

According to Sirieix et al. (2011), research has indicated that the combination of a good wine list and a supportive wine service (e.g. the recommendation of a particular wine, opening and pouring of wine and responding to questions related to the wines offered) has a positive influence on customer satisfaction and loyalty and can contribute to the financial success of a restaurant. Similarly, Oliveira-Brochado and Silva (2014) found that restaurateurs can use the restaurant's wine list strategically to sell wine as a complement to the meal menu and to increase customer satisfaction, loyalty and value perception. Davis and Charters (2006) remark that the selection of wine from a restaurant wine list is an experience that highlights the boundaries and importance of context in terms of consumer behaviour. As the consumer has to select wine from a set wine list (i.e. where a subset of choices is provided), the compilation and management of restaurant wine lists is an aspect that warrants further investigation.

Lockshin, Cohen and Zhou (2011) argue that although restaurants are an important channel for wine distribution in many countries, there is a dearth of research on how restaurant wine lists are compiled. More recent research confirmed that the situation has not changed since the observation made by Lockshin et al. in 2011 (Bonn, Cho \& Um 2018; Bruwer \& Campusano 2018), as the increased interest in wine and wine consumption escalated, scant research attention has been paid to the importance of using a wine list as part of a restaurant's differentiation strategy. Sirieix et al. (2011) undertook some pioneering research in this regard. However, their research endeavours have been confined to the role of wine lists in restaurants in only four countries, namely France, Australia, the United States and China. The emphasis of Sirieix et al.'s research (2011) specifically focused on measuring the relative importance of factors that restaurateurs considered when selecting wines for their respective restaurant wine lists. Because of the limited research activities related to the use of wine lists for the selection of wines in restaurant settings, as indicated above, the objective of this research is to replicate the work of Sirieix et al. (2011) in a South African context.

\section{Literature review of wine in a restaurant setting}

Wine is considered as an important component in many western-style restaurants and wine sales can contribute significantly to the restaurant's offering and profitability (Sirieix \& Remaud 2010). As wine is a complex product to purchase, many consumers experience uncertainty and anxiety (also known as 'perceived risk') in the process of deciding on a wine (Lacey, Bruwer \& Li 2009). For example, Ritchie (2007) found that participants in a study conducted among UK wine consumers indicated that the purchase of wine in a restaurant (on-trade) environment was perceived as much more stressful than the purchase of wine in a supermarket (off-trade) environment.

The maximisation of profit is likely to be a major factor for any restaurateur. Moreover, wine generally tends to have a higher markup than food in restaurants and it is therefore a vital profit centre for restaurateurs. The profit to be generated by wine will cause restaurateurs to invest a great deal of their time in the analysis of selecting the right price and value combinations of the wines they plan to offer (Lockshin et al. 2011). The price and other wine-related characteristics such as year, range, cultivar and origin of the wines that restaurants aspire to offer to their target market also have a large impact on the layout, lighting, décor and other elements that constitute the atmosphere of the restaurant. Fine dining restaurants (the restaurants of this study) demand a welldesigned, diligently managed atmosphere that does justice to and renders a desired customer experience. Wine plays an important role in this respect.

An important tool that on-trade establishments, such as restaurants and pubs, can use to introduce their patrons to the wines and stimulate sales of these wines is a wine list (Corsi, Mueller \& Lockshin 2012). According to Ben Dewald (2008), a common practice that restaurants use is to categorise the wines into white, red and sparkling wines, and then to group these wines by variety and/or origin within each of these subcategories. On many restaurant wine lists, a description of the sensory qualities of the wine along with the brand, vintage, origin and price is also supplied. Ben Dewald (2008) argues that a persistent theme in the literature is the recommendation that wine lists should be user-friendly.

The restaurant wine list can provide value and prestige as well as an emotional experience that may be full of surprises and information (Hwang \& Kunc 2015). Saura et al. (2008) consequently suggest that a careful analysis of the content and appearance of a wine list can be critical to add value and to position the restaurant in a well-differentiated manner.

Restaurateurs should also consider the expectations and perceived risks of their customers when they plan and compile their wine lists (Davis \& Charters 2006). In the pioneering study conducted by Sirieix et al. (2011), 11 factors that could influence restaurant owners' selection of wines for their wine lists were identified from an extensive literature review. These factors were matching wine with food, wellknown or popular brands (i.e. wines that are well known in a specific area), a competitive price that is fit for the price range of food, maximisation of profit, wine that tastes good, a balance of wine varieties, wines that are not available in retail stores, highly reputable brands (i.e. wines with a highquality reputation), a preference for local wine products, popular wines (i.e. supermarket-type wines with a large 
market share) and restaurateurs' reliance on their supplier's recommendations.

As indicated above, various factors influence the composition of a wine list. The factors identified in the literature review, as well as those in the study replicated, are discussed in the following section.

\section{Matching wine and food}

Various study disciplines (including psychology, sociology and anthropology) recognise the symbolic connection between food and alcohol (Pettigrew \& Charters 2006). The basic premise is that red wine should be served with meat, white wine with fish, champagne with caviar and port with cheese (Harrington 2005). Harrington (2005) consequently argues that appropriate wine and food pairings could not only lead to increased dining experiences, but also to higher profits for the restaurateur through wine sales. Even though the interest in wine and food pairing has continued to grow in popularity since the late 1990s, limited empirical research on the relationships between the pairing variables has been conducted (Harrington 2005; Harrington \& Seo 2015; Pettigrew \& Charters 2006).

\section{Maximisation of profit}

Bowen and Morris (1995) found that a restaurant menu could be used as both a communication instrument and a sales tool. Because the sale of wines can make a significant contribution to restaurant profits, it is essential that restaurateurs pay careful attention to the ways in which the wines of the restaurant are selected and promoted (Manske \& Cordua 2005). In restaurants, wine is often regarded as an essential profit generator (Wine Business Solutions 2015) and many restaurateurs know that a well-designed wine list can assist in improving restaurant revenues (Yang \& Lynn 2009). Sloan (2004) therefore believes that as wine is often the product with the highest profit margin for the restaurant, a strong focus on promotional and sale techniques is frequently necessary to assist customers in their choice of wine in a restaurant setting.

\section{Competitive price fit for the price range of food}

The pricing of wine is a critical aspect for winemakers and depends on various wine-related factors such as the appellation, taste, vintage, winemaker and available rankings (Coqueret 2015). From a restaurateur's perspective, the pricing of wine is also an important factor when developing wine lists as a balance between value for money and maximum profits needs to be maintained (Lockshin et al. 2011). Coqueret (2015) notes that the price of a bottle of wine is usually between two and five times higher in a restaurant than in a retail store or on a specialised Internet website. Smith (2015) quotes Emile Joubert, a South African wine marketing consultant, who observes that the markup of a bottle of wine in a typical South African restaurant can be three or more times higher than the winery's trade price.
According to Coqueret (2015), previous researchers have found mixed results on the impact of the price of wine on wine consumption and suggest that more research is needed to address this research gap.

\section{Reliance on supplier's recommendations}

As mentioned earlier, wine is an important profit contributor to many restaurants, and therefore the relationship between the wine supplier and the restaurateur is vital. Restaurateurs should establish a sound relationship with their wine suppliers to ensure that the ordered wine products are received in a timely and cost-effective manner. Similarly, wine suppliers can assist the restaurateur in the promotion of wine, employee training, pricing suggestions and recommendations for the pairing of wine with the restaurant's food (Dodd, Gultek \& Guydosh 2004). It can hence be foreseeable that many restaurateurs select wine for their wine lists based on the recommendations and advice received from those wine suppliers with whom they have established a sound relationship.

\section{Well-known or admired brands}

Adding admired or well-known wine brands to their wine lists to improve customer choice, satisfaction and ultimately sales can prove profitable for restaurateurs (Sirieix \& Remaud 2010). As wine is a complex and varied product, the assumption can be made that many restaurant patrons may select admired or well-known wine brands to reduce perceived risk and increase satisfaction. Furthermore, wellknown or admired wine brands are also memorable elements of special occasions such as birthdays and anniversaries.

\section{Taste of the wine}

The taste of a wine is an important intrinsic cue that can significantly influence the purchase decision of wine consumers (Cohen 2009). Results of a study conducted in the United Kingdom indicated that the taste of a wine was regarded as the most important risk experienced by consumers when buying a bottle of wine, while the opportunity to taste a wine before purchasing it was seen as the most important risk-reducing strategy (Mitchell \& Greatorex 1988). A study conducted among generation $X$ and $Y$ consumers in the United States also confirmed that the attribute of having 'tasted the wine previously' was regarded as most important from a list of 13 wine attributes when consumers purchased a bottle of wine (Chrysochou et al. 2012).

\section{Balance of wine varieties}

Lockshin et al. (2011) reason that as modern consumers tend to have more sophisticated palates, restaurants should offer both depth and breadth in their wine selections to satisfy consumers' need for choice. The addition of new and rare wine varieties to wine lists could be an advantageous tool to differentiate restaurants. It can also create a memorable experience for restaurant patrons (Lockshin et al. 2011). 


\section{Preference for local wine products}

Restaurateurs have the option to add wines from the region where the restaurant is located to support the local wine industry. A further reason for adding wines from the surrounding areas is that it may assist a large number of restaurant patrons with their wine selection as these wines may be more familiar to them, thereby reducing risks in their wine selection process. Consumers who have seen the vineyards, visited the wineries or have met the winemaker form a personal relationship with the wine, which is essential to the development of a wine culture (Gultek, Dodd \& Guydosh 2005).

\section{Wines not available in retail stores}

Sirieix et al. (2011:503) included the attribute of wines not being available in retail stores in their study as they believed that restaurateurs might want to add wines to the wine list that consumers could not find in retail stores. This would emphasise the exclusivity of the restaurant, but would also reduce the ability of consumers to compare the restaurant price of wine to the retail price of wine.

\section{Highly reputable brands (i.e. wines with a high-quality reputation)}

Highly reputable brands tend to receive reviews and ratings of well-known and respected wine critics. These bystatements are published in wine magazines and daily newspapers. Many wine drinkers follow comments and ratings by well-known and respected wine critics. Restaurateurs add brief extracts of the wine critics to the descriptions of highly reputable brands. Typical descriptions of highly reputable brands would, for instance, describe a particular Cabernet Sauvignon in respect of its flavours and aromas such as vanilla, currants, high alcohol levels and strong tannins.

\section{Popular wines (i.e. supermarket-type wines with a large market share)}

Because supermarkets have been granted the right to sell wines, many brands formerly not affordable to wine drinkers have become very popular because of now being able to be purchased by wine drinkers. The purchasing power of supermarket groups enables them to negotiate prices that enable them to offer wines at very affordable prices to their customers. Many of the wines bought at supermarkets have become very popular and have become the preferred choice for many wine drinkers. For restaurateurs, offering these popular wines will enforce the perception of value for money offered.

The factors that influence restaurateurs' choices in respect of wine on a wine list in this study are the same as those used by Sirieix et al. (2011). The major reason for this is to make comparisons with Sirieix et al.'s work possible. Furthermore, the study also endeavoured, in line with Sirieix et al.'s findings to identify guidelines that could be of value to
South African wine suppliers and their distributors. It was expected that South African wine suppliers and their distributors could, in particular, benefit from the findings of the New World (the United States, Australia and China) countries studied by Sirieix et al. (2011). In our literature review, we could not find any major differences in wine list design between countries, and we therefore did not expect to find the opposite in this study.

\section{Methodology}

\section{Sampling, questionnaire and data collection}

The restaurants included in the study had to meet three criteria: firstly, they had to be known for fine dining; secondly, a restaurant could not be part of a franchise; and thirdly, the wines a restaurant sold could not be limited to wines produced on their own wine estate. The requirement in respect of 'fine dining' was to ensure that the restaurants have sufficient similar characteristics for purposes of comparison. Wine lists of fine dining restaurants also tend to involve restaurant patrons more in the sense of wine selection. In the case of most franchised outlets, decisions in respect of wines are made at 'head office' with little or no input from individual franchisees or consideration of local preferences. The third requirement was purely to avoid any bias in favour of the particular estate's own wines. Access to the restaurants was largely dependent on access to the owner or manager of the restaurant. The restaurants included were all part of those restaurants that have been acknowledged for their fine dining and are located in Cape Town, Paarl, Franschhoek and Stellenbosch. Considering the exploratory nature of the study and the fact that there was no complete list available of restaurants in the Western Cape that complied with all the criteria for inclusion in the sample, non-probability convenience sampling was used to identify potential participants. The questionnaire used was similar to the one used by Sirieix et al. (2011), but was adapted, where necessary, to make provision for South African brands and terminology. Restaurant owners or managers were approached personally and requested to take part in the research. The questionnaires were, similar to the process followed in the Sirieix et al. (2011) study, completed by the restaurateurs during the personal visit. Data were collected during personal interviews with 61 owners or managers of restaurants that offered fine dining. The five samples assessed in the Sirieix et al. (2011) study varied in size from 40 to 74 respondents per sample.

\section{Analysis of data collected}

The Best-Worst (B-W) methodology was applied to investigate restaurateurs' preferences of strategies when compiling their wine lists. Initially developed by Finn and Louviere (1992), the B-W methodology has gained considerable support among researchers as it offers greater discriminating power than other scale measures. The B-W methodology has been used on a large scale in recent years to gain a better understanding and appreciation of 
wine consumers' preferences (Cohen 2009). Essentially, the methodology compels respondents to make trade-offs between clearly stated alternatives, attributes or propositions and customer preferences. Information on aspects such as the restaurant's size, the number of bottles of wine sold, the use of sommeliers or wine experts, corkage charged, pricing and wine suppliers were also gathered and are reported elsewhere in this article.

\section{Ethical considerations}

This article followed all ethical standards for research without direct contact with human or animal subjects.

\section{Results \\ Characteristics of the sample}

Some of the more salient characteristics of the sample studied are set out in Table 1 .

More characteristics of the sample are set out in Appendix 1.

\section{Results of the best-worst scaling}

The respondents were provided with 11 factors that were also representative of the strategies that could be considered when compiling a wine list. These strategies, in turn, each consisted of a choice set of six factors. Table 2 contains all 11 factors from which the respondents could choose to create a strategy.

A respondent had to select the 'most important' and 'least important' reason why they would choose a particular strategy. This had to be done for each of the 11 strategies. The calculation of the individual B-W scores for each of the possible individual factors was calculated as follows: firstly, an assessment value of $-1,0$ or +1 was allocated according to each individual reason. A value of -1 was given to the least preferred reason specified by a respondent, whereas the most preferred reason indicated by a respondent was given a value of +1 . A score of nil ( 0$)$ was given to a specific reason if it was not selected as the most or least preferred of the six factors that made up a specific strategy. This means that for each reason a value of $-1,0$ or +1 was assigned and the total for each reason was the sum total of all the scores for each reason over the 11 strategies.

The nil (0) option for the non-selecting of a reason, in other words the reason was neither the most nor the least preferred reason for a particular strategy, can be justified on the grounds that each reason was equally absent or present over the 11 strategies. Each one of the 11 factors was an option 6 times in each of the 11 strategies. The number of times a particular reason could be chosen as 'most important' or 'least important', thus varied between +6 and -6 . Appendix 2 comprises the individual scores per respondent for each of the 11 strategies. The values in Appendix 2 were calculated according to the procedure set out in the preceding sentences.
TABLE 1: Salient characteristics of the sample of restaurants studied.

\begin{tabular}{|c|c|}
\hline Questions asked & Responses from restaurateurs \\
\hline $\begin{array}{l}\text { Average number of customers served } \\
\text { per week? }\end{array}$ & On average 310 customers per week \\
\hline $\begin{array}{l}\text { Are customers allowed to bring their } \\
\text { own wine? }\end{array}$ & $\begin{array}{l}\text { Yes: } 48 \text {; No: } 13 \text {. If yes - corkage fee: R35 } \\
\text { average (R16-R85) }\end{array}$ \\
\hline $\begin{array}{l}\text { Does the restaurant have a cellar or a } \\
\text { temperature-controlled area to store } \\
\text { wines? }\end{array}$ & Yes: 37; No: 24 \\
\hline $\begin{array}{l}\text { Does the restaurant have a sommelier, } \\
\text { wine manager or wine supervisor? }\end{array}$ & Yes: 27; No: 34 \\
\hline $\begin{array}{l}\text { Who is in charge of designing the } \\
\text { wine list? }\end{array}$ & $\begin{array}{l}\text { Chef: 3; Owner: 39; Sommelier: 8; } \\
\text { Other: } 11\end{array}$ \\
\hline Frequency of updating the wine list? & $\begin{array}{l}\text { Every } 3 \text { months or more regular: } 28 \text {; Every } \\
6 \text { months: 8; Annually: } 25\end{array}$ \\
\hline Number of suppliers & On average $12 ;$ median $=8$ \\
\hline Bottles of wine sold per week? & On average 150 \\
\hline Markup on wines & $\begin{array}{l}\text { Median }=100 \% \text { (varies from } 25 \% \text { to } \\
300 \% \text { ) }\end{array}$ \\
\hline $\begin{array}{l}\text { Percentage of total sales contributed } \\
\text { by wine }\end{array}$ & $\begin{array}{l}\text { Average }=29 \% \text {; range between } 10 \% \text { and } \\
75 \%\end{array}$ \\
\hline $\begin{array}{l}\text { Importance of wine sales for the } \\
\text { business }\end{array}$ & $\begin{array}{l}55 \text { of the } 61 \text { respondents rated wine's } \\
\text { importance as } 5 \text { or more on a 7-point scale }\end{array}$ \\
\hline $\begin{array}{l}\text { Most popular way to promote wine in } \\
\text { the restaurant }\end{array}$ & $\begin{array}{l}\text { Recommendations by trained staff are the } \\
\text { most popular way to promote wine }\end{array}$ \\
\hline
\end{tabular}

TABLE 2: Factors that made up the different strategies.

\begin{tabular}{ll}
\hline No. & Factor \\
\hline 1 & Matching wine with food menu \\
2 & Tastes good (sommelier or restaurateur likes the taste) \\
3 & Competitive price fit for the price range of food \\
4 & Balance of varieties \\
5 & Preference for local wine products \\
6 & Popular wines (easy to sell because of high demand) \\
7 & Maximisation of profit (can apply a higher markup) \\
8 & Well-known or admired brand (e.g. Nederburg) \\
9 & Not available in retail stores \\
10 & Highly reputable brand (e.g. Kanonkop) \\
11 & Reliance on supplier's recommendation \\
\hline
\end{tabular}

The B-W scores that each factor obtained in this study are presented in Table 3. The mean score of each individual B-W score (difference between individual best and worst score divided by the number of respondents) is also shown for this study and for the study of Sirieix et al. From Table 3 it is clear that the respondents of this study (South Africa) regarded matching wine with the food menu as the most important factor when selecting wine for the wine list of their restaurant (1.426) followed by the fact that the wine should taste good (1.213). When compared to the results of the study by Sirieix et al., it is clear that these two factors were also deemed to be the two most important factors by the respondents in their study. The third most important factor for the sample of South African respondents was the balance of wine varieties (1.115), whereas the fourth most important factor for these respondents was the competitive price fit for the price range of the food. Interestingly, the respondents in the Sirieix study had a different point of view on these factors and regarded a competitive price for the price range of the food as the third most important factor (1.098) and the balance of wine varieties as fourth most important (0.731). Respondents from both studies indicated the preference for local wine products as the fifth most important factor, while popular wines were deemed by respondents of both studies as the sixth most important factor when selecting wine for their restaurant wine list. 
TABLE 3: Factors selected as most or least preferred by South African restaurateurs compared with that of the Sirieix study.

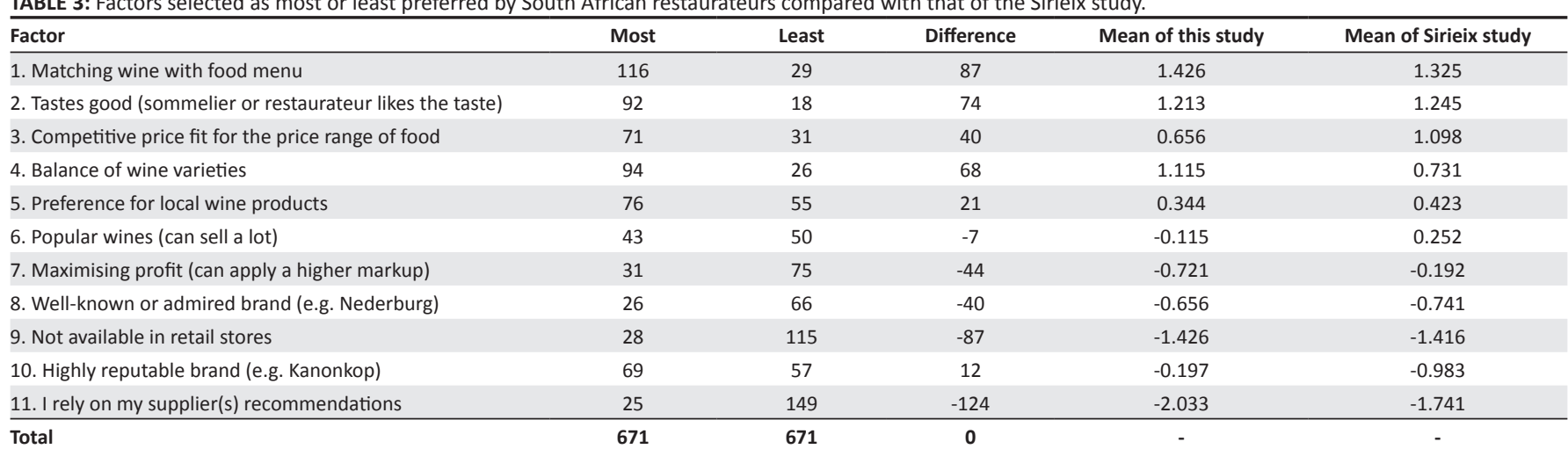

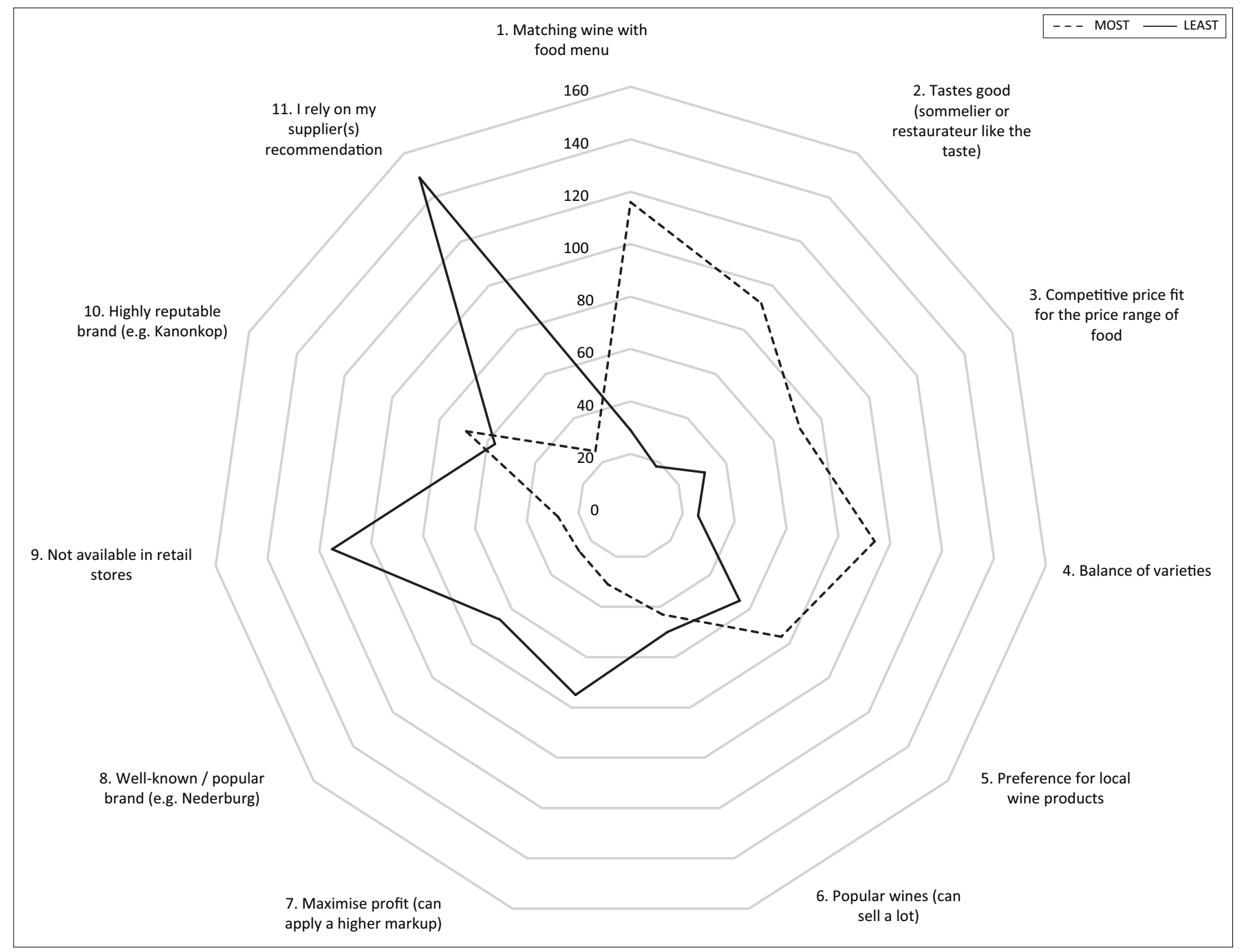

FIGURE 1: Rating of the factors selected as most or least preferred by respondents.

In terms of the factors that were regarded as less important when selecting wine for their restaurant wine list, similarities between the two studies were also found (Table 3). In both studies the respondents indicated that the factor that was least important when selecting wine for the wine list is the recommendations of supplier(s). In terms of the other less important factors, the respondents of the Sirieix study regarded the maximisation of profit as the seventh most important factor (-0.192), followed by the selection of a well-known or admired brand (-0.741) and a highly reputable brand (-0.983). Results of the South African study show that a highly reputable brand was deemed to be the seventh most important factor (-0.197), followed by a well-known or admired brand (-0.656) and maximising profit $(-0.721)$ in the ninth place. Respondents from both studies regarded the fact that the wine should not be available in retail stores as the 10th most important factor. The results of the South African study are also graphically illustrated in Figure 1. 


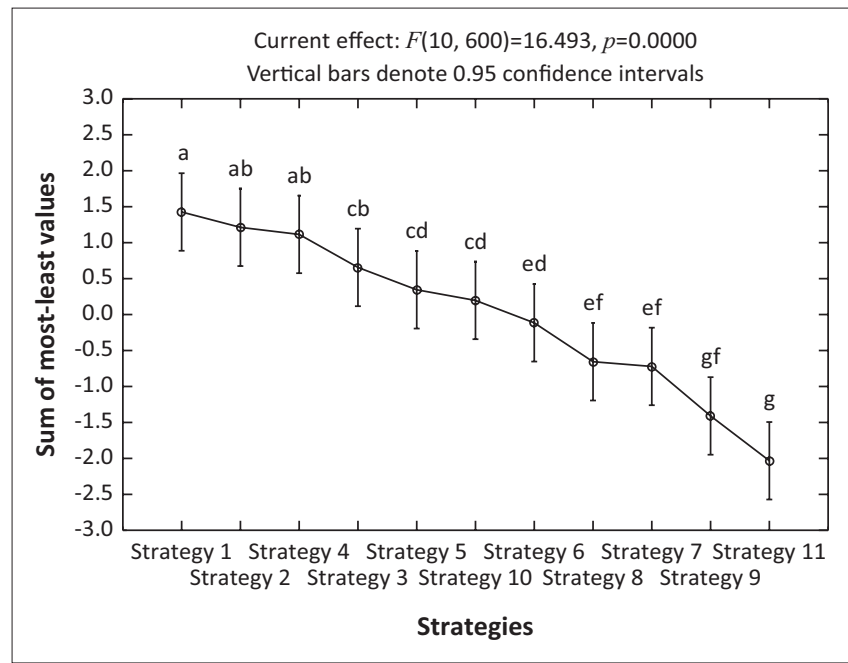

FIGURE 2: Average score per strategy of all strategies for all respondents.

As wine contributes on average $29 \%$ to the turnover of restaurants, it is by implication of great importance to customer satisfaction and restaurateurs.

Based on the literature review, the argument was made that the results of the South African study in terms of factors that are important in wine list design should not differ significantly from studies conducted in other countries. The results, however, indicate that there are not only similarities but also differences between South Africa and other countries. Similar to the study that was replicated (Sirieix et al. 2011), the factor that was deemed most important by restaurateurs when selecting wine for a wine list is that the wine should match the food on the menu. The argument can be made that if there is a 'good fit' between the food and the wine, the restaurant patron might have an enhanced dining experience that could lead to various positive outcomes such as positive word-of-mouth, higher food and wine sales and ultimately more profit. The factor that was deemed to be the second most important (in both studies) is the taste of the wine. Similar to the previous argument in terms of food and wine pairing, it can be argued that if restaurateurs select 'pleasant tasting wine' for their wine lists, sales and ultimately profits should increase.

If one considers the six most important factors in this study, as well as the Sirieix study, only one difference is observed. This difference is that South African restaurateurs rank 'balance of varieties' (range of wine for selection) as more important than a 'competitive price fit for the price range of the food'. It might therefore be advantageous for restaurateurs of fine dining South African restaurants to increase the depth and breadth of their wine selection by, for example, including more wine cultivars, vintages, estates and also rare wines to enhance customer satisfaction and ultimately experience and profit.

In terms of the least preferred factors, it is interesting to see that respondents from both studies regarded recommendations from their suppliers as the least important
TABLE 4: An example of one of these choice sets (strategies).

\begin{tabular}{ll}
\hline No. & Strategy 5: Factors \\
\hline 1 & Matching wine with food menu \\
2 & Preference for local wine products \\
3 & I rely on my supplier(s) recommendation \\
4 & Highly reputable brand (e.g. Kanonkop) \\
5 & Balance of varieties \\
6 & Not available in retail stores \\
\hline
\end{tabular}

factor when selecting wine for their wine lists. This insight is especially important for wine suppliers, as it seems that their advice or recommendations are not highly regarded by restaurateurs. Further investigation as to why this might be the case should be valuable for suppliers of wine to fine restaurants. Another interesting finding is that not only South African restaurateurs, but also restaurateurs in the Sirieix study do not seem to select wine for the wine list to make maximum profit (i.e. wines with a higher markup). A possible reason might be that restaurateurs understand that when they enhance customer satisfaction (e.g. by providing wine that matches their food offering as well as wines that taste good) their profits will increase because of factors such as increased wine sales, more frequent restaurant visits and positive word-of-mouth.

In addition to the importance of the 11 individual factors that were investigated, we also tested for the significant differences or similarities between different strategies. These strategies composed of the 11 different choice sets that were presented to the respondents.

An example of one of these choice sets (strategies) is Table 4 .

We also tested for the significant differences or similarities between strategies. Figure 2 shows the average score per strategy of all the strategies for all the respondents. The results in Figure 2 display the significant differences or similarities between the strategies. The alphabetical letter above the scores in Figure 2 indicates if there is a significant difference between the particular strategy and other strategies. One common alphabetical letter (e.g. 'a') indicates that there is not a significant difference between the particular strategy and other strategies that also have the common alphabetical letter (a) above the average value. Strategies with two alphabetical letters above the average value ( $a$ and $b$ for strategies 2 and 4 ) indicated in Figure 2 do not differ significantly from one another. Although strategies 1,2 and 4 appear to be very similar in their rating, there are no significant differences among these strategies. Strategy 3 is significantly lower than strategy 1 , but it is not significantly different from strategies 2 and 4 .

The most preferred strategy identified in this study, namely strategy 1, consists of the factors set out in Table 5. A calculation for the compilation of the strategy scores is shown in Appendix 2 (rating of the individual strategy options of responses by all respondents). 
TABLE 5: Factors for the most preferred strategy: Strategy 1.

\begin{tabular}{ll}
\hline No. & Strategy 1: Factors \\
\hline 1 & Balance of wine varieties \\
2 & Competitive price fit for price range of food \\
3 & Well-known or popular brand (e.g. Nederburg) \\
4 & Not available in retail stores \\
5 & Maximising profit (can apply a higher markup) \\
6 & I rely on my supplier(s) recommendations \\
\hline
\end{tabular}

The individual factors rated by the respondents are set out in Table 3. Figure 1 provides a graphic illustration of the factors displayed in Table 3.

The reason selected as the most preferred for inclusion on a wine list by the respondents was that a wine should match well with the food offered (selected 116 times by respondents). The second and third most selected factors were 'balance of varieties' and 'tastes good (sommelier or restaurateur likes the taste)'. The reason that was least preferred to be included in the respondents' wine list was the reliance on a supplier's recommendation (Table 6).

\section{Discussion of findings and conclusions}

Table 4 shows the factors underlying the strategy that are most preferred by respondents, whereas the factors set out in Table 3 are those that combined to form the least preferred strategy for respondents. An observation of the factors set out in the two tables indicates that factors such as competitive price fit for the price range of foods, the balance of varieties and reliance on a supplier's recommendations are part of both the best and worst strategy. When the results of this study are compared with the aggregate results of the Sirieix et al. study (2011), three of the factors of the most preferred strategy that emerged in this study are similar to those outlined by Sirieix et al. These three factors are indicated in Table 7 , with a correction mark (' $\checkmark$ ') next to the reason. However, two of the factors from the least preferred strategy of this study were part of the most preferred strategy of Sirieix et al. These two factors are indicated with a cross (x) next to the particular reason in Table 7.

As stated earlier, the results of the study indicate that there are similarities and differences between South Africa and the countries studied by Sirieix et al. (2011). The most important factor for restaurateurs when selecting wine for a wine list, namely matching the food on the menu, indicates that if there is a 'good fit' between the food and the wine, the restaurant patron might have an enhanced dining experience that could lead to various positive outcomes. The second most important factor (in both studies), namely the taste of the wine, will, likewise to the most important factor, result in positive outcomes such as positive word-of-mouth, higher food and wine sales and ultimately more profit.

Relatively speaking, the minor differences between the findings of the current study and that of Sirieix et al. (2011) indicate that as far as the perceptions of the South African
TABLE 6: Factors for the least preferred strategy: Strategy 11.

\begin{tabular}{ll}
\hline No. & Strategy 11: Factors \\
\hline 1 & Competitive price fit for price range of food \\
2 & I rely on my supplier(s) recommendation \\
3 & Tastes good (sommelier or restaurateur likes the taste) \\
4 & Popular wines (can sell a lot) \\
5 & Matching wine with food menu \\
\hline
\end{tabular}

TABLE 7: Factors selected as most preferred by respondents in the Sirieix et al. study (2011).

\begin{tabular}{ll}
\hline Preference & Factor \\
\hline 1 & Matching wine with the food menu $X$ \\
2 & Tastes good $X$ \\
3 & Competitive price fit for the price range of food $\checkmark$ \\
4 & Balance of varieties $\checkmark$ \\
5 & Preference for local wine products \\
6 & Popular wines $\checkmark$ \\
\hline
\end{tabular}

restaurateurs are concerned, South African wine consumers do not possess a distinct wine culture that warrants consideration when a wine list is designed.

These differences in findings clearly indicate that the factors that were found to explain decisions in a particular geographical area cannot merely be accepted as factors for decision-making in other areas.

\section{Limitations of the study and suggestions for future research}

A major limitation of this study could be the number of respondents. Although the number of respondents in this study was more or less similar to the samples used in the Sirieix et al. study of 2011, one can justifiably ask whether a larger sample would have produced different results. A convenient sample was used and only those restaurateurs who were willing to take part in the study were included. Another limitation could be the fact that respondents had to consider six factors for each of the strategies. This number could have resulted in respondent fatigue. Another limitation of this study (or any study of a similar nature) is that respondents might not be prepared or be reluctant to discuss or disclose promotion arrangements that they negotiated with suppliers. It is especially the major suppliers that are able to offer extensive and/or lucrative promotion deals to restaurants.

Suggestions for future research are the use of a bigger sample and perhaps using only four factors to consider per strategy at a time. A further suggestion is to compare restaurants from the study area (i.e. the wine-producing area) with those restaurants that do not have easy access to wine estates, winemakers and other people working in the wine industry and that are situated further away from the Western Cape. The factors investigated in this study could be extended to provide more insights. For instance, the rather low ranking of profit maximisation could be very different for other types of restaurants. A final suggestion for future research is to obtain the input of restaurateurs to draft a list of the factors they 
consider when compiling their wine lists. In the latter case, one would investigate reasons limited to South Africa specifically.

\section{Acknowledgements}

The authors declare that they have no financial or personal relationship or other interest that may have influenced them in any way when this article was written. Both authors wish to acknowledge the role of Ms Kelly Truter in the collection and capturing part of the data.

\section{Competing interests}

The authors declare that they have no financial or personal relationships that may have inappropriately influenced them in writing this article.

\section{Authors' contributions}

Each author equally contributed to all parts of the article.

\section{Funding}

This research received no specific grant from any funding agency in the public, commercial, or not-for-profit sectors.

\section{Data availability statement}

Data sharing is not applicable to this article as no new data were created or analysed in this study.

\section{Disclaimer}

The views and opinions expressed in this article are those of the authors and do not necessarily reflect the official policy or position of any affiliated agency of the authors.

\section{References}

Aune, L., 2002, 'The use of enchantment in wine and dining', International Journal of Contemporary Hospitality Management 14(1), 34-37. https://doi. org/10.1108/09596110210415105

Ben Dewald, B.W.A., 2008, 'The role of the sommeliers and their influence on US restaurant wine sales', International Journal of Wine Business Research 20(2), 111-123. https://doi.org/10.1108/17511060810883740

Bonn, M.A., Cho, M. \& Um, H., 2018, 'The evolution of wine research: A 26 year historical examination of topics, trends and future direction', International Journal of Contemporary Hospitality Management 30(1), 286-312. https://doi. org/10.1108/IJCHM-09-2016-0521

Bowen, J.T. \& Morris, A.J., 1995, 'Menu design: Can menus sell', International Journal of Contemporary Hospitality Management 7(4), 4-9. https://doi. org/10.1108/09596119510091699

Bruwer, J. \& Campusano, P., 2018, 'Restaurants and the bring-your-own-bottle of wine paradox: Involvement influences, consumption occasions, and risk perception' Journal of Foodservice Business Research 21(2), 121-138. https://doi.org/10.10 80/15378020.2017.1332888

Chrysochou, P., Krystallis, A., Mocanu, A. \& Lewis, R.L., 2012, 'Generation Y preferences for wine: An exploratory study of US market applying the best-worst scaling', British Food Journal 114(4), 516-528. https://doi.org/10.1108/00070701211219531

Cohen, E., 2009, 'Applying best-worst scaling to wine marketing', International Journal of Wine Business Research 21(1), 8-23. https://doi.org/10.1108/17511060910948008

Coqueret, G., 2015, 'Optimal wine pricing for restaurants', Journal of Wine Economics 10(2), 204-224. https://doi.org/10.1017/jwe.2015.19

Corsi, A.M., Mueller, S. \& Lockshin, L., 2012, 'Let's see what they have what consumers look for in a restaurant wine list', Cornell Hospitality Quarterly 53(2), 110-121. https://doi/org/10.1177/1938965511428448
Davis, N., \& Charters, S., 2006, 'Building restaurant wine lists: A study in conflict', in Third International Wine Business Research Conference, Montpellier, France, July 6-8, pp. 1-16.

Dodd, T.H., Gultek, M.M. \& Guydosh, R.M., 2004, 'Restaurateurs' perceptions of wine supplier attributes', Journal of Foodservice Business Research 7(3), 73-92. https:// doi.org/10.1300/J369v07n03_06

Finn, A. \& Louviere, J.J., 1992, 'Determining the appropriate response to evidence of public concerns: The case of food safety', Journal of Public Policy and Marketing 11(1), 12-25, viewed 30 January 2019, from http://about.jstor.org/terms.

Gultek, M.M., Dodd, T.H. \& Guydosh, R.M., 2005, 'Restaurateurs' attitude toward local wines and its influence on local wine purchases', International Journal of Wine Marketing 17(3), 5-24. https://doi.org/10.1108/eb008792

Harrington, R.J., 2005, 'The wine and food pairing process: Using culinary and sensory perspectives', Journal of Culinary Science \& Technology 4(1), 101-112. https://doi. org/10.1300/J385v04n01_11

Harrington, R.J. \& Seo, H., 2015, 'The impact of liking of wine and food items on perceptions of wine-food pairing', Journal of Foodservice Business Research 18(5), 489-501. https://doi.org/10.1080/15378020.2015.1093455

Hemingway, E., 1932, Death in the afternoon, Scribner, New York.

Hwang, J. \& Kunc, M., 2015, 'Business dynamics of on-premise wine trade: Cases from South Korea', International Journal of Wine Business Research 27(3), 239-254. https://doi/org/10.1108/IJWBR-08-2014-0034

Keown, C. \& Casey, M., 1995, 'Purchasing behaviour in the Northern Ireland wine market', British Food Journal 97(1), 17-20. https://doi.org/10.1108/ 00070709510077935

Lacey, S., Bruwer, J. \& Li, E., 2009, 'The role of perceived risk in wine purchase decisions in restaurants', International Journal of Wine Business Research 21(2), 99-117. https://doi.org/10.1108/17511060910967962

Lockshin, L., Cohen, E. \& Zhou, X., 2011, 'What influences five-star Beijing restaurants in making wine lists?', Journal of Wine Research 22(3), 227-243. https://doi.org/1 $0.1080 / 09571264.2011 .596200$

Manske, M. \& Cordua, G., 2005, 'Understanding the sommelier effect', Internationa Journal of Contemporary Hospitality Management 17(7), 569-576. https://doi. org/10.1108/09596110510620645

Mitchell, V. \& Greatorex, M., 1988, 'Consumer risk perception in the UK wine market', European Journal of Marketing 22(9), 5-15. https://doi.org/10.1108/ EUM0000000005296

Oliveira-Brochado, A. \& Silva, R., 2014, 'The wine list design by upscale restaurants', World Academy of Science, Engineering and Technology, International Science Index 88, International Journal of Social, Behavioral, Educational, Economic, Business and Industrial Engineering 8(4), 1052-1056. https://doi. org/10.1999/1307-6892/9997962

Peng, C., Bilgihan, A. \& Kandampully, J., 2015, 'How do diners make decisions among casual dining restaurants? An exploratory study of college students', Internationa Journal of Hospitality \& Tourism Administration 16(1), 1-15. https://doi.org/10.1 080/15256480.2015.991985

Pettigrew, S. \& Charters, S., 2006, 'Consumers' expectations of food and alcohol pairing', British Food Journal 108(3), 169-180. https://doi.org/10.1108/ 00070700610650990

Ritchie, C., 2007, 'Beyond drinking: The role of wine in the life of the UK consumer', International Journal of Consumer Studies 31(5), 534-540. https://doi. org/10.1111/j.1470-6431.2007.00610.x

Saura, I.G., Molina, M.E.R. \& Contrí, C.B., 2008, 'Qualitative and quantitative engineering criteria of restaurant wine lists', Journal of Wine Research 19(1), 19-31. https://doi.org/10.1080/09571260802164012

Sirieix, L. \& Remaud, H., 2010, 'Exploring wine list design strategy in French restaurants', paper presented at the 5th International Academy of Wine Business Research Conference, Auckland, NZ, 8-10th February.

Sirieix, L., Remaud, H., Lockshin, L., Thach, L. \& Lease, T., 2011, 'Determinants of restaurant owner/managers selection of wines to be offered on the wine list', Journal of Retailing and Consumer services 18(6), 500-508. https://doi. list', Journal of Retailing and Consumer
org/10.1016/j.jretconser.2011.06.012

Sloan, D., 2004, Culinary taste, consumer behavior in the international restaurant sector, Elsevier Butterworth-Heinemann, Oxford.

Smith, C., 2015, 'Restaurants' mark-up of wine leaves sour taste', Fin24, viewed 04 April 2016, from https://www.fin24.com/myfin24/restaurants-mark-up-of-wineleaves-sour-taste-20150206.

The Department of Agriculture, Forestry and Fisheries (RSA), 2017, Quarterly Economic Review of the Food and Beverages Industry in South Africa, April-June 2017, viewed 22 May 2018, from http://www.nda.agric.za/doaDev/sideMenu/ AgroProcessingSupport/docs/Draft $\% 20$ FB $\% 20 Q 2 \% 202017 \% 20 \% 20 \% 20(2) \% 20$ - \%20edited $\% 20(3) \% 20$ with $\% 20$ corrections $\% 20$ final.pdf.

Top Wine SA, n.d., Memorable wine quotes, viewed 22 May 2018, from http://www. topwinesa.com/about-wine/wine-quotes/.

Wine Business Solutions, 2015, The Wine Paper 36 - July 2015, viewed 29 August 2016 from https://winebusinesssolutions.com.au/wp-content/uploads/2015/08/TheWine-Paper-36.pdf.

Yang, S.S. \& Lynn, M., 2009, 'Wine list characteristics associated with greater wine sales', Cornell Hospitality Report 9(11), 6-14, viewed 30 January 2019, from https://scholarship.sha.cornell.edu/cgi/viewcontent.cgi?article=1169\&context= chrpubs. 


\section{Appendix 1: Data of the responding restaurateurs}

Size of restaurant

Seats in restaurant

Average number of customers served per week

Customers allowed to bring their own wine

Cellar or a temperature-controlled area to store wines

Sommelier/wine manager/wine supervisor

Person in charge of designing the wine list for restaurant

Frequency of updating wine list

Number of suppliers

Wine suppliers and approximate percentage (in money terms) bought from each

Average number of bottles of wine sold per week

Average markup on wines

Average amount spent per person in restaurant per meal (all meals, wines, taxes, etc. included)

Importance of wine sales in business.

Percentage of total sales contributed by wine

Ways of promoting wines in restauran

\begin{tabular}{|l|l|l|}
\hline$<70 \mathrm{~m}^{2}$ & $70-120 \mathrm{~m}^{2}$ & $>120 \mathrm{~m}^{2}$ \\
2 & 19 & 40 \\
\hline
\end{tabular}

\begin{tabular}{|l|l|l|l|l|l|}
\hline$<30:$ & $30-50:$ & $51-100:$ & $101-150:$ & $151-200:$ & $>200:$ \\
1 & $\mathbf{1 1}$ & $\mathbf{2 5}$ & 10 & 10 & 4 \\
\hline
\end{tabular}

310 customers per week

\begin{tabular}{|l|l|l|}
\hline Yes & No & If yes - Corkage fee: \\
$\mathbf{4 8}$ & $\mathbf{1 3}$ & R35 (R16-R85) \\
\hline
\end{tabular}

\begin{tabular}{|l|l|l|}
\hline Yes: $\mathbf{3 7}$ & & No: $\mathbf{2 4}$ \\
\hline
\end{tabular}

\begin{tabular}{|l|l|l|}
\hline Yes: $\mathbf{2 7}$ & & No: $\mathbf{3 4}$ \\
\hline
\end{tabular}

\begin{tabular}{|l|l|l|l|l|}
\hline Chef: $\mathbf{3}$ & Owner: $\mathbf{3 9}$ & Sommelier: $\mathbf{8}$ & Distributor: $\mathbf{0}$ & Other: $\mathbf{1 1}$ \\
\hline
\end{tabular}

\begin{tabular}{|l|l|l|}
\hline $\begin{array}{l}\text { Every } 3 \text { months or more regular: } \\
\mathbf{2 8}\end{array}$ & $\begin{array}{l}\text { Every } 6 \text { months: } \\
\mathbf{8}\end{array}$ & $\begin{array}{l}\text { Annually: } \\
\mathbf{2 5}\end{array}$ \\
\hline
\end{tabular}

Average $=\mathbf{1 2}$ and median $=\mathbf{8}$

\begin{tabular}{|l|l|l|l|l|l|l|l|}
\hline Winery & $70 \%$ & Wholesaler & $60 \%$ & Retailer & $\mathbf{6 0 \%}$ & Other & $\mathbf{2 0 \%}$ \\
\hline
\end{tabular}

150 bottles

Median $=100 \%$ : (varies from $25 \%$ to $300 \%$

\begin{tabular}{|l|l|l|}
\hline R76-R100 & R101-R150 & More than R150 \\
\hline $\mathbf{1 0}$ & $\mathbf{1 4}$ & $\mathbf{3 7}$ \\
\hline
\end{tabular}

\begin{tabular}{|l|l|l|l|l|l|l|}
\hline Not important Scale values Very important \\
\hline 1 & 2 & 3 & 4 & 5 & 6 & 7 \\
\hline $\mathbf{1}$ & $\mathbf{1}$ & $\mathbf{4}$ & $\mathbf{8}$ & $\mathbf{8}$ & $\mathbf{7}$ & $\mathbf{3 2}$ \\
\hline Number of respondents
\end{tabular}

\section{$29 \%$ (varies between $10 \%$ and $75 \%$ )}

\begin{tabular}{|l|}
\hline 49 \\
\hline 19 \\
\hline 27 \\
\hline 27 \\
\hline 39 \\
\hline 12 \\
\hline Other \\
\hline
\end{tabular}

My staff are trained about the wine we sell, so they can recommend to customers We offer a wine promotion (e.g. display card on table) We offer the client the opportunity to taste the wine before they order it We organise wine events at the restaurant (with winemakers, etc.) We suggest a wine that matches best with the dish We do not promote the wine Demonstration, displays, tasting 


\section{Appendix 2}

TABLE 1-A2: Individual scores per strategy per respondent.

\begin{tabular}{|c|c|c|c|c|c|c|c|c|c|c|c|}
\hline Respondents & 1 & 2 & 3 & 4 & 5 & 6 & 7 & 8 & 9 & 10 & 11 \\
\hline 1 & 5 & 3 & 1 & 0 & -2 & -3 & -1 & 0 & 2 & 0 & -5 \\
\hline 2 & 0 & 0 & 5 & -5 & 4 & 2 & 0 & 0 & -3 & 0 & -3 \\
\hline 3 & 1 & 3 & 1 & 0 & -1 & -3 & -4 & -2 & 6 & -1 & 0 \\
\hline 4 & -3 & 0 & 3 & 4 & -1 & 4 & 0 & 0 & -6 & 0 & -1 \\
\hline 5 & 0 & 2 & -1 & 2 & 6 & -3 & -5 & -1 & 0 & -1 & 1 \\
\hline 6 & 6 & 0 & 0 & 3 & 2 & 0 & -4 & 0 & -3 & 0 & -4 \\
\hline 7 & 5 & 3 & 0 & 3 & 0 & -3 & 0 & -2 & 0 & -4 & -2 \\
\hline 8 & -1 & 0 & -1 & -2 & -2 & 1 & 0 & 3 & -2 & 5 & -1 \\
\hline 9 & 2 & 1 & 0 & 4 & 4 & 0 & 0 & -5 & -1 & -4 & -1 \\
\hline 10 & 1 & 4 & 4 & 2 & 0 & -1 & -1 & 0 & -5 & 0 & -4 \\
\hline 11 & 6 & -1 & 0 & -1 & -3 & -2 & 0 & 1 & -1 & 1 & 0 \\
\hline 12 & 1 & -1 & 0 & -2 & -1 & 0 & 0 & 0 & 1 & 1 & 1 \\
\hline 13 & 6 & 2 & -2 & 2 & 0 & -1 & 0 & -2 & -5 & 0 & 0 \\
\hline 14 & 1 & -1 & 1 & 1 & -2 & 2 & 0 & 1 & -1 & -1 & -1 \\
\hline 15 & 1 & -1 & 2 & 0 & -2 & -1 & -1 & 0 & 1 & 2 & -1 \\
\hline 16 & 0 & -1 & 1 & 2 & -2 & 0 & 1 & 0 & -3 & 2 & 0 \\
\hline 17 & 1 & 1 & 3 & 2 & 0 & -2 & -1 & 0 & -3 & 2 & -3 \\
\hline 18 & 3 & 3 & 1 & 0 & 0 & -6 & -1 & -3 & 2 & 2 & -1 \\
\hline 19 & -4 & 0 & 2 & 4 & 4 & -1 & 1 & -1 & 0 & -1 & -4 \\
\hline 20 & 5 & 0 & -1 & 1 & 0 & 2 & -4 & 0 & -3 & 3 & -3 \\
\hline 21 & 3 & 1 & -1 & 1 & -4 & 0 & 0 & 0 & -2 & 6 & -4 \\
\hline 22 & 3 & 1 & -1 & 1 & -4 & 0 & 0 & 0 & -2 & 6 & -4 \\
\hline 23 & 3 & 1 & -1 & 1 & -4 & 0 & 0 & 0 & -2 & 6 & -4 \\
\hline 24 & 3 & 1 & -1 & 1 & -4 & 0 & 0 & 0 & -2 & 6 & -4 \\
\hline 25 & 3 & 1 & -1 & 1 & -4 & 0 & 0 & 0 & -2 & 6 & -4 \\
\hline 26 & 0 & 2 & 0 & 0 & 6 & -1 & 0 & -3 & -1 & -5 & 2 \\
\hline 27 & 1 & 1 & 1 & 2 & 1 & 1 & 2 & -1 & -5 & 0 & -3 \\
\hline 28 & 3 & 2 & 0 & 6 & -2 & -1 & 0 & 0 & -3 & 0 & -5 \\
\hline 29 & 2 & 6 & 1 & -1 & 0 & 2 & -2 & 0 & -4 & 0 & -4 \\
\hline 30 & 1 & 3 & 2 & -3 & -1 & 0 & -1 & 0 & -1 & 1 & -1 \\
\hline 31 & -3 & 0 & 0 & 0 & 1 & -1 & 0 & 3 & 1 & -2 & 1 \\
\hline 32 & -2 & 0 & 0 & 0 & -1 & 1 & 1 & -3 & -1 & 2 & 3 \\
\hline 33 & 2 & -1 & 0 & 3 & 1 & -3 & -2 & 0 & 1 & -1 & 0 \\
\hline 34 & -1 & 1 & -1 & 1 & 1 & -2 & -1 & 2 & -1 & -1 & 2 \\
\hline 35 & 3 & 2 & 0 & 6 & -1 & 0 & -3 & 0 & -6 & 0 & -1 \\
\hline 36 & 0 & 0 & 0 & 0 & 0 & 1 & 1 & -2 & 0 & 1 & -1 \\
\hline 37 & -3 & -2 & -1 & -1 & 1 & 2 & -3 & 2 & 2 & 4 & -1 \\
\hline 38 & 0 & 4 & 1 & 0 & 1 & 0 & 0 & 1 & -1 & -2 & -4 \\
\hline 39 & 2 & 1 & 0 & 2 & -2 & 2 & 3 & 0 & -2 & -2 & -4 \\
\hline 40 & 1 & 0 & -2 & 0 & 0 & -1 & 1 & 1 & 1 & -1 & 0 \\
\hline 41 & 0 & 1 & 3 & -2 & 4 & 2 & 0 & 0 & -5 & 0 & -3 \\
\hline 42 & -4 & 1 & -2 & 3 & 3 & 1 & 2 & 0 & -1 & 1 & -4 \\
\hline 43 & 5 & 2 & 1 & 1 & 2 & -3 & -6 & -1 & 0 & -1 & 0 \\
\hline 44 & 6 & 2 & 2 & 0 & 1 & 0 & -1 & -4 & -1 & 0 & -5 \\
\hline 45 & 4 & 3 & -2 & 1 & 2 & 1 & -2 & -2 & -1 & -2 & -2 \\
\hline 46 & 2 & 3 & 0 & 2 & 4 & 0 & 0 & -1 & -6 & -2 & -2 \\
\hline 47 & 1 & 2 & 0 & 0 & 5 & 1 & 1 & -2 & 1 & -3 & -6 \\
\hline 48 & 3 & 5 & 0 & 2 & 1 & -1 & 0 & -5 & 0 & -4 & 0 \\
\hline 49 & 1 & 0 & 2 & -2 & 1 & 1 & 2 & 1 & -6 & 3 & -3 \\
\hline 50 & 3 & 4 & 2 & 2 & -1 & -1 & 0 & -1 & -1 & -1 & -6 \\
\hline 51 & 0 & 1 & -1 & 2 & 1 & 1 & -6 & 0 & 1 & 1 & 0 \\
\hline 52 & -1 & -1 & 3 & 3 & 1 & 1 & -1 & -2 & 2 & -3 & -2 \\
\hline 53 & 0 & 1 & 0 & 6 & 1 & -2 & -4 & 0 & -4 & -1 & 3 \\
\hline 54 & 1 & 1 & 0 & 0 & 2 & 3 & -3 & 1 & -4 & 1 & -2 \\
\hline 55 & 0 & 0 & 4 & 2 & 3 & 1 & -2 & 1 & -6 & 0 & -3 \\
\hline 56 & 0 & 0 & 6 & 1 & 3 & 1 & 0 & -3 & -2 & -5 & -1 \\
\hline 57 & 0 & 0 & 2 & 2 & 1 & -1 & 3 & -4 & 2 & 0 & -5 \\
\hline 58 & 1 & 2 & 1 & -1 & -3 & 5 & -2 & 1 & -3 & 1 & -2 \\
\hline 59 & 2 & 1 & 2 & 0 & 2 & -1 & -2 & -2 & 1 & 0 & -3 \\
\hline 60 & 3 & 1 & 3 & 2 & -1 & 0 & 1 & -2 & 1 & -3 & -5 \\
\hline 61 & 3 & 4 & -1 & 4 & 0 & -1 & 0 & -4 & 0 & 0 & -5 \\
\hline
\end{tabular}

